\title{
PERLINDUNGAN HUKUM TERHADAP WISATAWAN DALAM PASOKAN JASA PARIWISATA OLEH BIRO PERJALANAN WISATA
}

\author{
Oleh: \\ Princess Innez Primantara ${ }^{1}$
}

\begin{abstract}
Purpose of this research is identify the construction norms about security and safety standard of tourist in the supply of tourism services by Tour Operator and the readiness Tour Operator in implementing tourists protection regulations in the supply of tourism services by Tour Operator. The research method used is a empirical legal research. Data and sources of data used are primary data, which derives from Tour Operator located around Denpasar and Badung, while secondary data used consisted of primary legal materials, secondary, and tertiary. Data collection techniques used are Study Documents Techniques and Interview Techniques, with the sampling technique used on the population is Non-Probability Sampling Techniques. The analysis used in this research is the Qualitative Data Analysis.

As from April 11, 2014, the Government has set rules on Standards Service of Business Travel through Regulation of the Minister of Tourism and Creative Economy Number 4 of 2014. This allows for Tour Operator standardization problem as provided in the ministerial regulations, and constraints experienced by the Tour Operator to fulfill that standardization. In this regard, it is necessary to study more about the implementation of the protection of the law by a Tour Operator, after the ministerial regulation.
\end{abstract}

Keywords : Tour Operator, Standardization, Legal Protection, Traveler's rights.

\section{PENDAHULUAN}

\section{a. Latar Belakang}

Usaha Jasa Perjalanan Wisata adalah perusahaan yang kegiatannya mengurus keperluan orangyangmengadakan perjalanan baik darat, udara, maupun laut dengan cara menjadi penghubung antara perusahaan yang menyediakan fasilitas perjalanan dengan orang yang ingin melakukan perjalanan. ${ }^{2}$ Usaha Jasa Perjalanan Wisata ini terdiri dari dua jenis, yaitu Biro Perjalanan Wisata dan Agen Perjalanan Wisata.

Mahasiswa Magister Ilmu Hukum Universitas Udayana, Denpasar, Bali. Alamat JL. Intan LC II Blok IV No. 11, Denpasar, e-mail: nez.tara13@gmail.com. I Gde Pitana dan I Ketut Surya Diarta, 2009, Pengantar Ilmu Pariwisata, CV. Andi Offset, Yogyakarta, hlm.124.
Jenis jasa perjalanan dapat berjalan dengan baik, apabila terjalin hubungan yang baik antara penyedia jasa perjalanan dengan pelanggan, sehingga dimungkinkan adanya hubungan jangka panjang dengan konsumen pengguna jasa tersebut, karena konsumen akan melakukan transaksi langsung dengan penyedia jasa. Hal tersebut yang membedakan jenis usaha jasa perjalanan dengan perusahaan manufaktur dimana konsumen tidak berhubungan langsung dengan produsen. ${ }^{3}$

\footnotetext{
Siti Nurhayati, 2009, Perlindungan Hukum Bagi Konsumen Pengguna Jasa Biro Perjalanan Menurut Undang-Undang Nomor 8 Tahun 1999 Tentang Perlindungan Konsumen, Jurnal, Volume 2 Nomor 2, Universitas Pembangunan Panca Budi, Medan.
} 
Suatu perusahaan dapat disebut sebagai

Biro Perjalan Wisata apabila kegiatan utama perusahaan tersebut ditekankan pada perencanaan dan penyelenggaraan perjalanan wisata atau paket wisata atas inisiatif sendiri dan tanggung jawab sendiri dengan tujuan mengambil keuntungan dari penyelenggaraan perjalanan tersebut. ${ }^{4}$ Dalam tujuannya untuk merencanakan kegiatan perjalanan wisatawan, Biro Perjalanan Wisata sering kali mengadakan berbagai macam bentuk paket wisata untuk menarik minat wisatawan yang akan datang ke suatu daerah wisata.

Terhitung sejak tanggal 11 April 2014, Pemerintah telah menetapkan peraturan tentang Standar Usaha Jasa Perjalanan Wisata melalui Peraturan Menteri Pariwisata dan Ekonomi Kreatif Republik Indonesia (Permenparekraf) Nomor 4 Tahun 2014. Dalam Pasal 9 ayat 4 (a) dijelaskan bahwa terdapat 3 aspek standar yang harus dipenuhi oleh biro perjalanan wisata 3 aspek, yaitu Aspek Produk, Aspek Pelayanan, dan Aspek Pengelolaan. Penjelasan secara detail terkait unsur-unsur tersebut dijelaskan lebih lanjut dalam Lampiran Permenparekraf tersebut.

Hal ini memungkinkan adanya masalah standarisasi Biro Perjalanan Wisata sebagaimana ditentukan didalam peraturan menteri, dan kendala yang dialami oleh Biro Perjalanan Wisata untuk memenuhi standarisasi. Peraturan tersebut belum

I Gusti Putu Bagus Sasrawan Mananda, 2011, "Studi Kelayakan Pendirian PT. Medussa Multi Bussines Center (MMBC) Sumanda Tour \& Travel di Bali (Kajian Aspek Pasar Finasial)", (tesis) Program Studi Magister (S2) Manajemen Pascasarjana Universitas Udayana, hlm.48. menentukan secara detail mengenai lembaga yang menguji standarisasi aspek produk, pelayanan, dan pengelolaan suatu Biro Perjalanan Wisata. Bagaimanakah standar tanggung jawab Biro Perjalanan Wisata yang telah ada sebelum berlakunya peraturan menteri tersebut? Perlindungan hukum terhadap pengguna jasa pariwisata baik domestik maupun mancanegara dan para pengusaha pariwisata sangat diperlukan. ${ }^{5}$ Karena apabila faktor keselamatan itu diabaikan, maka akan timbul dampak negatif terhadap daya saing produk jasa.

Pariwisata merupakan salah satu andalan dalam perolehan devisa bagi pembangunan baik nasional maupun daerah. Oleh sebab itu, pembangunan pariwisata Indonesia harus mampu menciptakan inovasi baru untuk mempertahankan dan meningkatkan daya saing secara berkelanjutan. ${ }^{6}$ Adanya penelitian ini diharapkan dapat memberikan saran dan masukan kepada pemerintah dan biro-biro perjalanan wisata, agar lebih bertanggung jawab dalam mengutamakan keselamatan wisatawan sesuai dengan standarisasi yang telah ditetapkan dalam suatu peraturan.

\section{b. Rumusan Masalah}

1. Bagaimanakah konstruksi norma pengaturan standar keamanan dan keselamatan wisatawan dalam pasokan jasa pariwisata oleh Biro Perjalanan Wisata?
Violetta Simatupang, 2009, Pengaturan Hukum Kepariwisataan Indonesia, PT. Alumni, Bandung, hlm.59.

6 Made Metu Dhana, 2012, Perlindungan Hukum dan Keamanan Terhadap Wisatawan, Paramita, Surabaya, hlm.1. 
2. Bagaimanakah kesiapan Biro Perjalanan Wisata dalammelaksanakan peraturan perlindungan wisatawan dalam pasokan jasa pariwisata oleh Biro Perjalanan Wisata?

\section{c. Tujuan Penelitian}

Adapun tujuan umum dalam penelitian ini, yaitu mengkaji bentuk tanggung jawab yang diberikan oleh Biro Perjalanan Wisata terhadap wisatawan. Sedangkan yang menjadi tujuan khusus dalam penelitian ini, yaitu :

a. Mengidentifikasi konstruksi norma pengaturan standar keamanan dan keselamatan wisatawan dalam pasokan jasa pariwisata oleh Biro Perjalanan Wisata.

b. Mengetahui kesiapan Biro Perjalanan Wisata dalam melaksanakan peraturan perlindungan wisatawan dalam pasokan jasa pariwisata oleh Biro Perjalanan Wisata.

\section{METODE PENELITIAN}

Jenis Penelitian dalam penelitian ini, yaitu Penelitian Hukum Empiris, karena penelitian ini menyangkut tentang data. ${ }^{7}$ Dalam penelitian ini, kesenjangan terlihat pada adanya aturan yang menyatakan bahwa suatu usaha jasa perjalanan wisata wajib memberikan perlindungan kepada wisatawan yang menggunakan jasanya. Sementara dalam prakteknya, belum semua Biro Perjalanan Wisata memberikan perlindungan hukum yang sesuai berkaitan dengan

Philipus M. Hadjon dan Titiek Sri Djatmiati, 2005, Argumentasi Hukum, Gadjah Mada University Press, Yogyakarta, hlm.2 keselamatan wisatawan yang menggunakan jasanya. Dimana paket-paket wisata yang ditawarkan terkadang belum sesuai dengan standarisasi produk yang aman diberikan kepada wisatawan.

Dalampenelitianini, dataprimerdidapat dari Biro Perjalanan Wisata yang berada di sekitar Denpasar dan Badung. Sedangkan data sekunder yang digunakan berasal dari data-data yang sudah terdokumentasi dalam bentuk bahan hukum primer, sekunder dan tersier.

Teknik pengumpulan data yang digunakan, yaitu Teknik Studi Dokumen dan Teknik Wawancara. Selanjutnya, Teknik Pengambilan sampel populasi penelitian dalam penelitian ini adalah Teknik Non Probability Sampling.

III. HASIL DAN PEMBAHASAN

a. Konstruksi Norma Pengaturan Standar Keamanan Dan Keselamatan Wisatawan Dalam Pasokan Jasa Pariwisata Oleh Biro Perjalanan Wisata

Apabila dikaji berdasarkan Teori Hukum Murni, adanya perjenjangan dalam pengaturan standarisasi dan sertifikasi usaha ini menunjukkan bahwa Hukum yang lebih rendah berdasar dan bersumber pada hukum yang lebih tinggi. Dibuatnya Permenparekraf ini, merupakan perintah dari Peraturan Pemerintah Nomor 52 Tahun 2012 tentang Sertifikasi Kompetensi dan Sertifikasi Usaha di Bidang Pariwisata, dan bersumber dari Undang-Undang Nomor 10 Tahun 2009 tentang Kepariwisataan. Oleh sebab itu, lahirnya Permenparekraf Nomor 
4 Tahun 2014 ini merupakan suatu bentuk pengaplikasian teori hukum murni, yang memiliki dasar peraturan yang jelas.

Standar Usaha Jasa Perjalanan Pariwisata yang dimaksud dalam Peraturan Menteri ini, sebagaimana disebutkan dalam pasal 1 angka 3, adalah Suatu perumusan terhadap klasifikasi Usaha Jasa Perjalanan Wisata dan/atau klasifikasi Usaha Jasa Pariwisata yang mencakup 3 (tiga) aspek utama, yaitu aspek pengelolaan, produk, dan pelayanan.

Selanjutnya, kewajiban Biro Perjalanan Wisata untuk memenuhi sertifikasi sebagaimana tercantum dalam pasal 9, terdapat dalam Pasal 7 ayat (1). Kata wajib, yang terdapat dalam ketentuan pasal tersebut mengartikan bahwa Sertifikat Usaha Jasa Perjalanan Wisat adalah sesuatu yang harus dimiliki oleh setiap usaha jasa perjalanan wisata, yang apabila tidak dipenuhi maka akan menimbulkan sanksi tertentu.

Dalam Pasal 9 dijelaskan terkait persyaratan yang harus dipenuhi untuk dapat melaksanakan sertifikasi usaha jasa perjalanan wisata, yaitu:

(1) Persyaratan dasar dan pemenuhan serta pelaksanaan standar usaha sebagaimana tercantum dalam lampiran Permenparekraf;

(2) Persyaratan dasar adalah Tanda Daftar Usaha Pariwisata (TDUP) Bidang Usaha Jasa Perjalanan Wisata;

(3) Sertifikasi dapat dilakukan apabila persyaratan dasar telah dipenuhi;

(4) Pemenuhan dan pelaksanaan Standar Usaha mencakup 3 (tiga) aspek:

a. Aspek Produk, yang didalamnya terdapat 20 unsur, yang wajib dipenuhi.

b. Aspek Pelayanan, didalamnya ditetapkan 7 unsur yang harus dipenuhi, dan

c. Aspek Pengelolaan, yang didalamnya tercantum 11 unsur, yang harus dipenuhi.

Menurut Muljadi A.J., Produk wisata adalah kumpulan dari berbagai macam jasa dimana antara satu dan lainnya memiliki keterkaitan dan dihasilkan oleh berbagai perusahaan pariwisata, seperti restoran/ tempat makan, akomodasi, daya tarik wisata, angkutan wisata, dan perusahaan lainnya yang terkait. ${ }^{8}$

Berkaitan dengan produk yang dihasilkan oleh Biro Perjalanan Wisata, Permenparekraf Nomor 4 Tahun 2014 mengatur tentang 20 unsur yang harus dipenuhi, yang terdiri dari 6 fokus utama, yaitu :

a. Disediakannya minimum jasa pemesanan dan/atau penjualan;

b. Minimal membuat 1 (satu) paket wisata sendiri, dan menyelenggarakan lebih dari 1 (satu) paket wisata;

c. Dalampaketwisata terdapatketerangan minimum tentang nama paket, waktu perjalanan, rangkaian kegiatan, harga dalam mata uang rupiah, jenis transportasi dan akomodasi yang digunakan, serta perlindungan asuransi bagi wisatawan;

Muljadi A.J., 2012, Kepariwisataan dan Perjalanan, Cetakan ke-3, PT. Rajagrafindo Persada, Jakarta, hlm.47. 
d. Disediakannya jasa pengurusan paspor dan visa;

e. Jasa pramuwisata yang digunakan adalah jasa mandiri atau bagian dari usaha jasa pramuwisata, yang memiliki sertifikat kompetensi;

f. Pimpinan perjalanan wisata (tour leader) yang dipekerjakan memiliki sertifikat kompetensi.

Sementara itu, pelayanan diartikan sebagai sebuah aktivitas yang sifatnya tidak kasat mata, dimana hal tersebut terjadi karena interaksi antara konsumen dengan pemberi jasa atau hal-hal lain yang disediakan oleh perusahaan untuk dapat memecahkan ataupun meringankan permasalahan konsumen. ${ }^{9}$ Dalam hal pelayanan, Permenparekraf Nomor 4 Tahun 2014, menetapkan 7 unsur yang harus dipenuhi, dengan 2 fokus utama, yaitu:

a. Menerapkan Standard Operating Procedures (SOP) bagi pelaksanaan tamu di kantor BPW;

b. Standard Operating Procedures (SOP) dalam pelaksanaan perjalanan wisata diterapkan dengan baik.

Pengelolaan yang wajib dilakukan oleh Biro Perjalanan Wisata berdasarkan Permenparekraf Nomor 4 Tahun 2014, mencakup 11 unsur, dengan 5 fokus utama, yaitu :

a. Tempat usaha terpisah dari ;

b. BPW memiliki tata kelola perusahaan;

c. Basis data tentang identitas wisatawan terpelihara dengan baik;

Ratminto dan Atik Septi Winarsih, 2005, Manajemen Pelayanan, Pustaka Pelajar, Jakarta, hlm.2. d. Adanya rencana pengembangan usaha;

e. Adanya pengembangan SDM.

Konsekuensi yang ditentukan oleh Permenparekraf Nomor 4 Tahun 2014, apabila Biro Perjalanan Wisata tidak memenuhi standar usaha tersebut diatur dalam Pasal 11 ayat (1), yang intinya menyatakan bahwa apabila ketentuan dalam Pasal 9 ayat (4) huruf a, tidak dipenuhi, maka usaha perjalanan wisata tersebut tidak dapat digolongkan dan tidak dapat mendalilkan diri sebagai Biro Perjalanan Wisata.

Sanksi terhadap Biro Perjalanan Wisata yang tidak memenuhi unsur-unsur sebagaimana diatur dalam Pasal 7 ayat (1) dan Pasal 13 Permenparekraf Nomor 4 Tahun 2014 pada jangka waktu yang ditentukan, adalah pelaku usaha akan dikenakan sanksi administratif berupa teguran tertulis, pembatasan kegiatan usaha, dan pembekuan atau pencabutan TDUP.

b. Kesiapan Biro Perjalanan Wisata Dalam Melaksanakan Peraturan Perlindungan Wisatawan Dalam Pasokan Jasa Pariwisata Oleh Biro Perjalanan Wisata

Adanya sertifikasi Biro Perjalanan Wisata dalam aspek produk, pelayanan, dan pengelolaan ini merupakan suatu langkah preventif. Dengan menjalankan sertifikasi ini dengan benar, biro perjalanan wisata akan mampu mendukung peningkatan mutu pariwisata dalam aspek produk, pelayanan, dan pengelolaan.

Hadirnya Permenparekraf Nomor 4 Tahun2014 yang baruditetapkan pada tanggal 11 April 2014 ini menimbulkan reaksi positif dari pelaku usaha. Hal tersebut menunjukkan 
bahwa sudah adanya kesadaran hukum dari pemerintah maupun pelaku usaha terkait, untuk menetapkan suatu standar terhadap produk, pelayanan, dan pengelolaan dari usaha perjalanan wisata.

Sementara itu, dalam Pasal 20 sampai 22 Permenparekraf Nomor 4 Tahun 2014 j.o. Permenparekraf Nomor 8 Tahun 2014, disebutkan bahwa usaha jasa perjalanan wisata wajib untuk memperoleh Sertifikat Usaha Jasa Perjalanan Wisata yang dikeluarkan oleh Lembaga Sertifikasi Usaha (LSU) Bidang Pariwisata, dalam jangka waktu 2 (dua) tahun terhitung sejak tanggal 11 April 2014.

Berdasarkan hasil penelitian penulis di Harum Indah Sari (HIS) Tours and Travel yang berkedudukan di Kota Denpasar, ada satu hal yang belum dipenuhi oleh HIS Tours and Travel dalam aspek pelayanan, yaitu belum adanya SOP tentang penanganan oleh tenaga pemandu wisata dan/atau pimpinan perjalanan wisata terhadap permasalahan dan keluhan yang muncul selama perjalanan wisata,. Belum terpenuhinya unsur tersebut disebabkan oleh adanya perbedaan budaya. Perbedaan budaya tersebut membuat perusahaan sulit untuk menentukan standar tepat yang dapat diberlakukan bagi seluruh wisatawan yang menggunakan jasa HIS Tour and Travel.

Sementara itu, penelitian penulis pada Rama Duta Tours and Travel yang berkedudukan di Kota Denpasar, menunjukkan bahwa terdapat 4 (empat) unsur dalam Permenparekraf Nomor 4 Tahun 2014 yang belum dipenuhi, terdiri dari 3 (tiga) unsur dalam aspek produk dan 1 (satu) unsur dalam aspek pelayanan, yaitu :

1. Belum dipenuhinya ketentuan minimum terhadap jasa pemesanan dan/atau penjualan jasa angkutan wisata;

2. Belum disediakannya jasa pengurusan paspor dan visa;

3. Belum adanya perlindungan asuransi perjalanan wisata yang diberikan kepada tenaga pemandu wisata;

4. Belum adanya SOP tentang untuk mengisi kuisioner untuk evaluasi terhadap perjalanan wisata oleh tenaga pemandu wisata dan/atau pimpinan perjalanan wisata kepada wisatawan.

Berkaitan dengan unsur-unsur yang belum dipenuhi tersebut, Monica Budiono mengungkapkan bahwa, untuk dapat memenuhi unsur-unsur dalam Permenparekraf Nomor 4 Tahun 2014 tersebut, pihaknya akan mempelajari peraturan tersebut secara lebih dalam, mengembangkan kerjasama dengan perusahaan yang bergerak dibidang pariwisata baik hotel, penerbangan, obyek wisata dan lain lain.

Menurut I.G.N. Parikesit Widiatedja, apabila dilihat dari sudut liberalisasi jasa, adanya perlindungan asuransi dapat menjadi alternatif solusi untuk meningkatkan pendapatan pariwisata secara keseluruhan. ${ }^{10}$ Sehingga ada baiknya bila Biro Perjalanan Wisata memberikan perhatian khusus terhadap asuransi kepada wisatawan.

I.G.N. Parikesit Widiatedja, 2010, Liberalisasi Jasa dan Masa Depan Pariwisata Kita, Udayana University Press, Denpasar, hlm.114. 
Hal serupa juga terjadi di Melali Bali, salah satu Biro Perjalanan Wisata yang berkedudukan di kabupaten badung. Menurut Ketut Jaman, selaku Managing Director Melali Bali, sekaligus sebagai Kepala Bidang (Kabid) SDM ASITA Bali, dalam wawancara tanggal 17 Maret 2015, menyatakan bahwa belum dipenuhinya unsur-unsur dalam Permenparekraf Nomor 4 Tahun 2014 ini disebabkan oleh belum adanya sosialisasi resmi dari pemerintah, sehingga menimbulkan ketidakjelasan dalam pelaksanaannya. Adapun beberapa unsur yang belum dipenuhi adalah sebagai berikut:

1. Paket wisata memuat keterangan tentang harga paket wisata dalam mata uang rupiah. Dalam hal ini, Ketut Jaman mengatakan bahwa keterangan mengenai harga paket wisata dicantumkan secara terpisah, yaitu dalam confidential tariff.

2. Paket wisata memuat keterangan tentang perlindungan asuransi perjalanan bagi wisatawan. Menurut Ketut Jaman, hal tersebut tidak selalu dicantumkan dalam paket wisata. Karena perlindungan asuransi merupakan penawaran tambahan yang diajukan sesuai dengan paket wisata yang dipilih oleh wisatawan. Sehingga wisatawan berhak memilih untuk menggunakan perlindungan asuransi tersebut ataupun tidak.

3. Tenaga Pemandu Wisata dilindungi asuransi perjalanan wisata. Dalam hal ini, Melali Bali bekerjasama dengan Himpunan Pramuwisata Indonesia (HPI), sehingga asuransi biasanya telah disediakan oleh HPI sesuai dengan rute perjalanan yang diikuti.

4. Tour Leader dilengkapi dengan sertifikat kompetensi yang masih berlaku.

Menurut Ketut Jaman, pengalaman adalah fokus utama dalam pemilihan pimpinan perjalanan wisata. Sehingga pimpinan perjalanan wisata dari Melali Bali tidak selalu memiliki sertifikat kompetensi.

5. Pimpinan Perjalanan Wisata dilindungi asuransi perjalanan wisata.

Serupa dengan pemandu wisata, pemberian asuransi perjalanan wisata kepada pimpinan perjalanan wisata disesuaikan dengan rute perjalanan yang diikuti, sehingga tidak semua pimpinan perjalanan wisata mendapatkan asuransi perjalanan wisata.

Disisi lain, selaku Kabid SDM ASITA Bali, Ketut Jaman menjelaskan bahwa ASITA belum mempersiapkan program khusus untuk menjalankan Permenparekraf Nomor 4 Tahun 2014 ini kepada anggotaanggotanya. Sejauh ini, fokus ASITA terhadap biro perjalanan wisata yang ingin bergabung menjadi anggotanya adalah kelengkapan perijinannya.

Sesungguhnya biro perjalanan wisata, khususnya yang berada di Kota Denpasar dan Kabupaten Badung telah siap untuk melaksanakan Permenparekraf tersebut. Karena sebelum adanya Permenparekraf tersebut, biro perjalanan wisata telahmemiliki standar tersendiri dalam menjalankan usahanya.

Namun kurangnya sosialisasi dari pemerintah mengesankan bahwa kurangnya koordinasi dan persiapan antara pemerintah 
dengan pelaku usahamaupunASITA., dimana hal tersebut tidak sesuai dengan Prinsip Penyelenggaraan Tata Kelola Pariwisata yang baik. Prinsip penyelenggaraan tata kelola kepariwisataan yang baik adalah adanya koordinasi dan sinkronisasi program antar pemangku kepentingan (stake holder), serta adanya partisipasi aktif yang terpadu dan saling menguatkan antara pemerintah, pihak swasta, dan masyarakat setempat yang terkait. $^{11}$

\section{SIMPULAN DAN SARAN \\ a. Simpulan}

Konstruksi norma pengaturan standar keamanan dan keselamatan wisatawan dalam pasokan jasa pariwisata oleh Biro Perjalanan Wisata adalah Permenparekraf Nomor 4 Tahun 2014 tentang Standar Usaha Pariwisata. Dimana Permenparekraf tersebut merupakan peraturan yang lahir atas dasar Peraturan Pemerintah Nomor 52 Tahun 2012 tentang Sertifikasi Kompetensi dan Sertifikasi Usaha di Bidang Pariwisata, dan bersumber dari Undang-Undang Nomor 10 Tahun 2009 tentang Kepariwisataan. Tujuan dibuatnya Permenparekrafini adalah untuk mendukung peningkatan mutu pelayanan, pengelolaan, dan produk, serta untuk meningkatkan daya saing usaha jasa perjalanan wisata, dengan cara memenuhi unsur-unsur sebagaimana ditentukan dalam Pasal 9 ayat (4) huruf a.

Sanksi yang diberikan kepada Biro Perjalanan Wisata yang tidak memenuhi

Bambang Sunaryo, 2013, Kebijakan Pembangunan Destinasi Pariwisata: Konsep dan Aplikasinya di Indonesia, Gava Media, Yogyakarta, hlm.77. unsur-unsur yang tercantum dalam Pasal 7 ayat (1) dan Pasal 13 Permenparekraf Nomor 4 Tahun 2014 pada jangka waktu yang ditentukan, yaitu pelaku usaha akan dikenakan sanksi administratif berupa teguran tertulis, pembatasan kegiatan Usaha Jasa Perjalanan Wisata, dan pembekuan atau pencabutan TDUP.

b. Saran

1. Diharapkan agar pemerintah dalammembuatperaturanmenterimelakukan kajian lebih dalam sebelum mengesahkan dan menentukan masa berlaku sebuah peraturan, sehingga nantinya peraturan-peraturan yang dihasilkan dapan berjalan dengan efektif dan efisien.

2. Pemerintah sebagai pihak yang bertugas untuk melaksanakan pembinaan dan pengawasan dalam rangka penerapan Standar Usaha Jasa Perjalanan, wajib untuk melakukan sosialisasi tentang Permenparekraf Nomor 4 Tahun 2014 kepada Biro Perjalanan Wisata di Provinsi Bali, dan mengadakan kerjasama-kerjasama dengan ASITA dan Lembaga Sertifikasi Usaha Pariwisata yang sudah disahkan oleh Kementerian Pariwisata dan Ekonomi Kreatif.

\section{DAFTAR PUSTAKA}

\section{a. Buku}

Pitana, I Gde dan I Ketut Surya Diarta, 2009, Pengantar Ilmu Pariwisata, CV. Andi Offset, Yogyakarta.

Nurhayati, Siti, 2009, Perlindungan Hukum Bagi Konsumen Pengguna Jasa Biro Perjalanan Menurut Undang- 
Undang Nomor 8 Tahun 1999 Tentang

Perlindungan Konsumen, Jurnal,

Volume 2 Nomor 2, Universitas

Pembangunan Panca Budi, Medan.

Mananda, I Gusti Putu Bagus Sasrawan, 2011, "Studi Kelayakan Pendirian

PT. Medussa Multi Bussines Center (MMBC) Sumanda Tour \& Travel di Bali (Kajian Aspek Pasar Finasial)", (tesis) Program Studi Magister (S2) Manajemen Pascasarjana Universitas Udayana.

Simatupang, Violetta, 2009, Pengaturan

Hukum Kepariwisataan Indonesia, PT. Alumni, Bandung.

Dhana, Made Metu, 2012, Perlindungan Hukum dan Keamanan Terhadap Wisatawan, Paramita, Surabaya.

Hadjon, Philipus M., dan Titiek Sri Djatmiati, 2005, Argumentasi Hukum, Gadjah Mada University Press, Yogyakarta.

J., Muljadi A., 2012, Kepariwisataan dan Perjalanan, Cetakan ke-3, PT. Rajagrafindo Persada, Jakarta.

Ratminto dan Atik Septi Winarsih, 2005, Manajemen Pelayanan, Pustaka Pelajar, Jakarta.

Widiatedja, I.G.N. Parikesit, 2010, Liberalisasi Jasa dan Masa Depan Pariwisata Kita, Udayana University Press, Denpasar.

Sunaryo, Bambang, 2013, Kebijakan

Pembangunan Destinasi Pariwisata: Konsep dan Aplikasinya di Indonesia, Gava Media, Yogyakarta. 